\title{
Foreign Aid and Economic Growth: A Panel Cointegration for Selected Turkic Republics
}

\begin{abstract}
Hasret Balcioglu'
ABSTRACT

This paper considers the relationship between external aid and economic growth in Azerbaijan, Georgia, Kazakhstan, Kyrgyzstan, Turkmenistan and Uzbekistan from 1992 to 2014. These countries have benefited positively from continuous aid inflows from Turkey. In this study, the model is a panel system with the variables real GNP per capita for country and Turkish aid. From the analysis, it could be understood that all the panel unit root tests show that each variable is integrated of the first order I (1) and there is strong evidence for panel cointegration between real GNP per capita and foreign aid for the selected countries. The country-specific elasticity of real income with respect to foreign aid for most of the countries is close to one. Therefore, it can be recommended that foreign capital flows can have more positive effect on real income with the supplements of domestic savings and complements of domestic resources. Thus, it is advisable for the countries to develop their capacities to optimize the benefits from international resources with supportive integration in international markets.
\end{abstract}

Keywords: Economic Growth, Foreign Capital Flows, Panel System, Turkey, Turkic Republics.

JEL Codes: C33, F35, O11

Available Online: 28-06-2016.

This is an open access article under Creative Commons Attribution 4.0 License, 2016.

\subsection{INTRODUCTION}

It is known that Turkic Republics have underdeveloped economies based on export of raw materials in exchange for assistance from Russia. With the collapse of the Soviet Union in 1991, it had been almost impossible for them to export their products (Gouliev, 1997; Vand derleeuw, 1997). These countries also struggle with low income level, high level of unemployment and low utilization level of industrial capacity. Therefore, after 1991, Turkic Republics have started a slow transition process which is called "from plan to market economy" through economic reforms and privatization (Melo et al., 1997; Aslund, 2001) but the inadequacy of the domestic economy to increase domestic revenue sources to finance the deficit by itself also makes inflows of foreign capital an important source to relieve the challenge. In

\footnotetext{
1 Department of Business Administration, Cyprus International University, North Cyprus, Mersin 10 Turkey, E-mail: hbenar@ciu.edu.tr
} 
consequence, the presence of these resource's gaps in one way or another shows that the domestic economy does nor have the capacity of generating enough finance to close these gaps and make the country's reliance on foreign capital inflow mandatory.

It is known that foreign aid is important as a source of income for the developing countries. It has come out as a dominant strategy for improving economic life conditions in the third world over the last half century. United Nations, World Bank and International Monetary Fund have gained the role of donor international institutes for the recipient countries (Hjertholm and White, 2003). This source of income can be divided into two main categories: Military and economic assistance. Foreign aid is given to developing countries, countries of strategic importance to the donor country and countries recovering from the war.

There are different views in the literature dealing with the impact of foreign aid on economic growth. For instance, Griffin and Enos (1970); Boone (1994); Easterly (1999); Knack (2000); Brautigam and Knack (2004) and Temitope (2013) indicate a negative relation between foreign aid and economic growth. These authors encourage the idea that foreign aid is completely consumed and it substitutes rather than compliments national resources.

There are some other studies (Singh, 1985; Lensink and Morrisey, 2000; Pallage and Robe, 2001) that make the explanation of the negative correlation between foreign aid and economic growth as the outcome of factors such as intervention of government, business cycles, economic policies and sustainability of foreign aid through the recipient countries. Some of the papers like Mosley, et al. (1987); Boone (1996); and Jensen and Paldam (2003) point out that foreign aid does not have any effect on economic growth.

Obstfeld (1999) indicates that lump-sum foreign policy does not have any effect on the steady-state capital stock or output level but it will increase the dynamic adjustment of steady state that begins below it. Some other studies, like Papanek (1973); Dowling and Hiemenz (1982); Gupta and Islam (1983); Hansen and Tarp (2000); Burnside and Dollar (2000); Gomanee, et al. (2003); Tavares (2003); Dalgaard et al. (2004); and Karras (2006); Fasanya and Onakoya (2012), show that there is positive correlation between foreign aid and economic growth.

The aim of this paper is to find out the relationship between the Turkish foreign aid and the economic growth in Azerbaijan, Georgia, Kazakhstan, Kyrgyzstan, Turkmenistan and Uzbekistan for the period 1992-2014. The period is selected with the consideration that Soviet Union has collapsed in 1991 and Turkey started to help those countries in the context of economy starting in the year of 1992. The selected countries are the Turkic Republics which benefit mostly from the aid of Turkey.

The study is most probably the first attempt to investigate the effect of foreign aid on the economic growth in this region using panel cointegration methodology. Panel cointegration test has significant more power that the standard cointegrations test for small samples (Hatemi-J and Irandoust, 2004).

This paper is structured in this way: Section two deals with the methodology with theoretical background. Section three explains research analysis and results while section four presents conclusions and recommendations.

\subsection{METHODOLOGY WITH THEORETICAL BACKGROUND}

In this study, the model is a panel system which is defined as follows:

$\operatorname{LnY} Y_{i t}=\alpha_{i}+\beta_{i} \ln A_{i t}+\varepsilon_{i t}$, for $i=1, \ldots, N$ and $t=1, \ldots, T$,

where $\ln Y_{i t}$ shows the log of real GNP per capita for country $i$ at time $t, \ln A_{i t}$ is the log of the Turkish aid to country $i$ at time $t$, and $\varepsilon$ is the stochastic error term. 
GNP per capita stands for a series of annual data and it is calculated by using population series in each country. Real US dollar is the currency used. Consumer price index of each country is used in order to deflate GNP and aid series. Data for consumer price index and GNP series were collected from International Financial Statistics and data for aid series were obtained from Turkish Coordination and Cooperation Agency (TIKA). The countries considered in this study are Azerbaijan, Georgia, Kazakhstan, Kyrgyzstan, Turkmenistan and Uzbekistan and the sample data for each country is used for the period of 1992-2014.

For making the necessary analysis, a panel version of Dickey-Fuller (1979) unit-root test is considered. It is known that Augmented Dickey-Fuller test statistics is one of the well-known test statistics for unit roots. The simplest form of the test is:

$\Delta \mathrm{x}_{\mathrm{t}}=\gamma \mathrm{x}_{\mathrm{t}-1}+\mathrm{e}_{\mathrm{t}}$

Shiller and Perron (1985) shows that the power of Dickey-Fuller unit-root test should be improved with the panel versions of the test which is recommended by Im, Pesaran and Shin (2003) since the test is not strong in small sample sizes. A panel version of the test is as follows:

$\left(\begin{array}{l}\Delta x_{1 t} \\ \Delta x_{2 t} \\ \cdots \\ \Delta x_{N t}\end{array}\right)=\left(\begin{array}{l}\gamma_{1} x_{1 t-1} \\ \gamma_{2} x_{2 t-1} \\ \cdots \\ \gamma_{N} x_{N t-1}\end{array}\right)+\left(\begin{array}{c}e_{1 t} \\ e_{2 t} \\ \cdots \\ e_{N t}\end{array}\right)$

where $\mathrm{N}$ shows the number of cross-sections. The null hypothesis of one panel unit root is $\gamma_{1}=\gamma_{2}=\ldots=\gamma_{N}=0$. The error terms are supposed to be white noise. Levin and Lin (1993) shows the panel unit root test:

$\Delta x_{i t}=\gamma_{i} x_{i t-1}+e_{i t}$, for $i=1, \ldots, N$ and $t=1, \ldots, T$

According to Levin and Lin (1993), the panel estimator can be defined:

$\operatorname{VNT}\left(\breve{Y}_{-1}\right)=\frac{(1 / V N) \sum_{i}(1 / T) \sum_{t}\left(x_{i t-1}\right) e_{i t}}{(1 / N) \sum_{i}\left(1 / T^{2}\right) \sum_{t}\left(x^{2}{ }_{i t-1}\right)}$ for $i=1, \ldots, N$ and $t=1, \ldots, T$.

where $\underset{i=1}{\mathrm{i}=\sum_{\mathrm{i}=1}^{\mathrm{N}}}$ and $\sum_{\mathrm{t}=1}^{\mathrm{T}} \mathrm{t}$

In order to test the null hypothesis of panel unit root, the following equation could be used:

$$
t_{\gamma}=\frac{\left(\breve{y}_{-1}\right) v\left(\sum i \sum_{t} x_{i t-1}\right)}{V\left[(1 / N T) \sum i{ }_{t} e^{2}{ }_{i t}\right]}
$$

It is clearly understood from the Monte Carlo experiments done by Levin, Lin and Chu (2002) that the power of the panel unit root test is significantly higher than the individual unit root tests.

A diverse coefficient of unit root test could be used by the Im-Pesaran-Shin (IPS) by Im et al. (2003) test and this encourages a mean of the individual Dickey-Fuller tests. The test with better size properties is written below:

$\mathrm{t}=(1 / \mathrm{N}) \sum \mathrm{t}_{\mathrm{i}}$ where $\mathrm{t}_{\mathrm{i}}$ is the individual $\mathrm{t}$-statistics for testing $\mathrm{H}_{0}: \gamma_{i}=0,-\mathrm{Vi}, \mathrm{i}=1, \ldots, \mathrm{N}$

The alternative hypothesis, $H_{1}$, in the IPS test is $\gamma_{i}<0$ for $i=N_{1}+1, \ldots, N$ where 
$\operatorname{Lim}=\mathrm{N}_{1} / \mathrm{N}=\mathrm{C}, 0<\mathrm{C} \leq 1$

$\mathrm{N} \rightarrow \infty$

Heterogeneity could be observed within the panel.

With the usage of panel data, running panel unit root tests is significant to prevent spurious regression. In order to test for panel cointegration, Pedroni $(1995,1996,1999)$ suggests the following test statistics:

a. Panel t-statistic (Parametric)

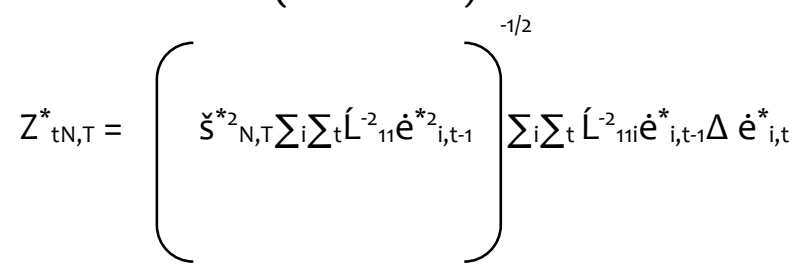

b. Panel t-statistic (Non-Parametric)

$$
Z_{\mathrm{tN}, \mathrm{T}}=\left(\bar{\sigma}^{2} \mathrm{~N}, \mathrm{~T} \sum_{\mathrm{i}} \sum_{\mathrm{t}} \mathrm{L}^{-2}{ }_{11} \dot{\mathrm{e}}_{\mathrm{i}, \mathrm{t}-1}\right)^{-1 / 2} \sum_{\mathrm{i}} \sum_{\mathrm{t}} \underline{L}^{-2}{ }_{11}\left(\dot{\mathrm{e}}_{\mathrm{i}, \mathrm{t}-1} \Delta \dot{\mathrm{e}}_{\mathrm{i}, \mathrm{t}} \lambda_{\mathrm{i}}\right)
$$

c. Group t-statistic (Parametric)

$$
N^{-1 / 2} \bar{Z}_{t N, T}=N^{-1 / 2} \sum_{i}\left(\sum \dot{s}^{*_{2}}{ }_{i} \dot{e}^{*_{i, t-1}}\right)^{-1 / 2} \sum_{t}\left(\dot{e}_{i, t-1} \Delta \dot{e}_{i, t}^{*}\right)
$$

d. Group t-statistic (Non-Parametric)

$$
\mathrm{N}^{-1 / 2} \bar{Z}^{*}{ }_{\mathrm{tN}, \mathrm{T}}=\mathrm{N}^{-1 / 2} \sum_{\mathrm{i}}\left(\bar{\sigma}_{\mathrm{i}} \sum_{\mathrm{t}}{\underline{L^{-}}}_{11} \dot{\mathrm{e}}_{\mathrm{i}, \mathrm{t}-1}\right)^{-1 / 2} \sum_{\mathrm{t}}\left(\dot{\mathrm{e}}_{\mathrm{i}, \mathrm{t}-1} \Delta \overline{\mathrm{e}}_{\mathrm{i}, \mathrm{t}}^{*} \bar{\lambda}_{\mathrm{i}}\right)
$$

where

$\bar{\lambda}_{i}=(1 / T) \sum_{s}\left(1-s /\left(k_{i}+1\right)\right) \sum_{t} \overline{\mu_{i, t}} \overline{\mu_{i, t}-s,}$ where $s=1, \ldots, k_{i}$ and $t=s+1, \ldots, T$

$\breve{S}^{2}{ }_{i}=(1 / T) \sum t \bar{\mu}_{i, t}, \quad \bar{\sigma}_{i}{ }_{i}=\check{S}^{2}{ }_{i}+2 \bar{\lambda}_{i}$

$\bar{\sigma}^{2}{ }_{N T}=(1 / T) \sum_{t}{ }^{2}{ }_{11 i} \sigma_{i}^{2}, \check{s}^{* 2}{ }_{i}=(1 / T) \sum_{t} \mu^{*{ }_{i}}{ }_{i, t}$

$\hat{L}^{2}{ }_{11 i}=(1 / T) \sum \eta^{2}{ }_{i, t}+(2 / T) \sum t\left(1-s /\left(k_{i}+1\right)\right) \sum \eta_{i, t} \eta_{i, t-s}$

The estimated error terms are obtained by the regressions written below: 


$$
\dot{\mathrm{e}}_{\mathrm{i}, \mathrm{t}}=\breve{y ̆}_{\mathrm{i}} \dot{\mathrm{e}}_{\mathrm{i}, \mathrm{t}-1}+\overline{\mu_{\mathrm{i}, \mathrm{t}}}
$$

$$
\dot{e}_{i, t=} \breve{y}_{i} \dot{e}_{i, t-1+}+\sum_{k=1}^{K_{i}} \breve{y}_{i, k} \Delta \dot{e}_{i, t-k}^{*}+\mu^{\bar{i}_{i, t}}
$$

$\Delta \ln \gamma_{i t}=b \Delta \ln A_{i t}+\eta_{i, t}$

where $\Delta$ is the first difference operator and the result of the equation is the standard normal distribution.

Pedroni (1995, 1996a, 1996b, 1997a, 1997b, 1998) recommends a few adjustments for both panel unit root tests and panel cointegration tests. The adjusted values are written in the manuscript to find the opportunity to compare the results with the standard normal distribution.

\subsection{RESEARCH ANALYSIS AND RESULTS}

All the panel unit root tests show that each variable is integrated of the first order I (1). After finding that all of the variables are non-stationary, it should be continued looking for cointegration which is the long-run steady state. Table 1 exhibits the estimated results for three Panel Unit Root Tests.

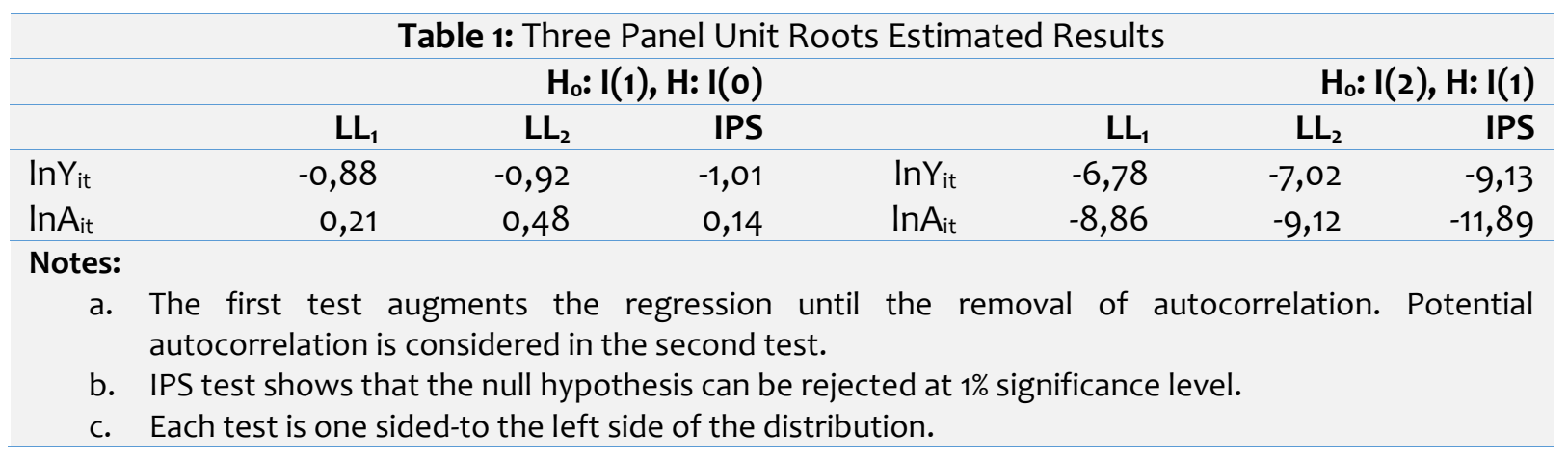

It can be seen that there is strong evidence for panel cointegration between real GNP per capita and foreign aid for the selected countries. Table 2 indicates the results obtained from the Pedroni's test.

\begin{tabular}{cccr|}
\hline \multicolumn{4}{|c|}{ Table 2: Pedroni Panel Cointegration Test for Real Aid and Real GNP per Capita } \\
\hline Test a & Test b & Test c & Test d \\
\hline-2.38 & -2.13 & -2.02 & -1.72 \\
\hline Source: by Author & & & \\
\hline
\end{tabular}

Tabulated data (in Table 2) show that the variables cointegrate in the panel view and three of the tests reject the null hypothesis (no cointegration) at the $1 \%$ significance level and one of them rejects the null hypothesis at the $5 \%$ significance level.

The tests are one sided therefore the $1 \%$ critical value is -1.96 , the $5 \%$ value is -1.64 and the $10 \%$ critical value is equal to $-1,28$. The adjusted values are comparable with one sided standard normal distribution, $\mathrm{N}(0.1)$. Test results suggest that there is significant long-run equilibrium in the panel. The next step is to estimate the parameters considered. In Equation (1), there is the estimation of panel system with the usage of the dummy least squares method. This helps us to find the country-specific elasticities. The estimated elasticities have been shown in Table 3.

From the table 3, it could be understood that the elasticity written in column 2 is the elasticity of GNP per capita per country with respect to aid coming from Turkey except the last row. The elasticities 
(individually and pooled) are estimated by letting the effects individually through dummy variables to consider the scale effect.

Table 3: The Foreign Aid Elasticities in the Long-run Period

\begin{tabular}{lrrr} 
Country & Elasticity & Standard Error & t-statistics \\
\hline Azerbaijan & 1.268 & 0.089 & 13.54 \\
Georgia & 1.135 & 0.075 & 12.47 \\
Kazakhstan & 0.865 & 0.054 & 9.84 \\
Kyrgyzstan & 0.954 & 0.098 & 7.75 \\
Turkmenistan & 1.021 & 0.120 & 11.25 \\
Uzbekistan & 0.562 & 0.066 & 8.82 \\
Pooled Data & 0.941 & 0.042 & 21.73 \\
\hline Source: by Author & & &
\end{tabular}

Each elasticities obtained is positive and statistically significant at any level of significance. From these elasticities, it can be realized that (keeping other factors constant), the foreign aid from Turkey is positively affecting the real per capita GNP of the Azerbaijan, Georgia, Kazakhstan, Kyrgyzstan, Turkmenistan and Uzbekistan. The last row in the table is important because it shows the foreign aid pooled elasticity. The elasticity is significant at all conventional significance levels and it also indicates that $10 \%$ increase in foreign aid results in $9 \%$ increase in GNP per capita in the group.

\subsection{CONCLUSIONS}

The study indicates the long-run relationship between foreign aid and real economic growth for the period 1992-2014. It concludes that the Turkish foreign aid has a significant positive impact on economic growth for Azerbaijan, Georgia, Kazakhstan, Kyrgyzstan, Turkmenistan and Uzbekistan. The countryspecific elasticity of real income with respect to foreign aid for most of the countries is close to one so it can be recommended that foreign capital flows can have more positive effect on real income with the supplements of domestic savings and complements of domestic resources. So, it is advisable for the considered countries to develop their capacities to optimize the benefits from international resources with supportive integration in international markets.

\section{REFERENCES}

Aslund, A. (2001). Transforming Post Communist Political Economies: Possible Future Directions for Economies in Transition, www.nap.edu.readingroom/books/transform/ch18htm

Boone, P. (1994). The impact of foreign aid on savings and growth, Center for Economic Performance, working paper 1265 , London.

Boone, P. (1996). Politics and the effectiveness of foreign aid. European Economic Review, 40: 289-329.

Brautigam, D.A. and Knack S. (2004). Foreign aid, institutions, and governance in Sub-Saharan Africa. Economic Development and Cultural Change, 13:255-285.

Burnside, C. and Dollar D. (2000). Aid, policies, and growth. American Economic Review, 90:847-868.

Dalgaard, C. J., Hansen, H. and Tarp F. (2004). On the empirics of foreign aid and growth. Economic Journal, 114: 191-216.

Dickey, D. A.; Fuller, W. A. (1979). Distribution of the Estimators for Autoregressive Time Series with a Unit Root. Journal of the American Statistical Association, 74 (366): 427-431.

Dowling, M. and Hiemenz U. (1982). Aid, Savings and Growth in the Asian Region. Economic Office Report Series 3, Asian Development Bank: Manila.

Easterly, W. (1999). The ghost of financing gap: testing the growth model used in international financial institutions. Journal of Development Economics, 60: 423-438.

Fasanya, I. O. and Onakoya A. B. O. (2012). Does Foreign Aid Accelerate Economic Growth? An Empirical Analysis for Nigeria. International Journal of Economics and Financial Issues, 2: 423-431.

Gomanee, K, Girma, S., Morrissey O. (2003). Searching for Aid Threshold Effects: Aid, Growth and the Welfare of the Poor. CREDIT Research Papero2/05, Centre for Research in Economic Development and International Trade, University of Nottingham, Nottingham. 
Gouliev, R. (1997). Petrol and Policy. Ar Publication Office, Istanbul.

Griffin, K.B., and Enos J. L. (1970). Foreign Assistance: Objectives and Consequences. Economic Development and Cultural Change, 18:313-327.

Gupta, K. L. and Islam M. A (1983). Foreign Capital, Savings and Growth-An International Cross-Section Study. Reidel Publishing Company: Dordrecht.

Hansen, H. and Tarp F. (2000). Aid effectiveness disputed. Journal of International Development, 12: 375-398.

Hatemi-J, A., and Irandoust M. (2004). Is pricing to market behaviour a long-run phenomenon? A nonstationary panel analysis. Emprica, 3:55-67.

Hjertholm, P. and White H. (2000). Survey of Foreign Aid: History, Trends, and Allocation. Discussion Papers, University of Copenhagen Institute of Economics.

Jensen, P. S., Paldam M. (2003). Can the New Aid-Growth Models Be Replicated?, Working Paper No.2003-17, Institute for Economics: Aarhus.

Karras, G. (2006). Foreign aid and long-run economic growth: empirical evidence for a panel of developing countries. Journal of International Development, 18, 7: 15-28.

Knack, S. (2000). Aid Dependence and the Quality of overnice: A Cross-Country Empirical Analysis, World Bank Policy Research Paper.

Lensink, R. and Morrissey O. (2000). Aid stability as a measure of uncertainty and the positive impact of aid on growth. Journal of Development Studies, 36: 31-49.

Melo, M. D., Denizer, C. and Tenev S. (1997). The Role of Initial Conditions and Policies in Transition Economies, Wb, IFC, WP

Mosley, P. Hudson, J. and Horrell S. (1987). Aid, the public sector and the market in less developed countries. Economic Journal, 97, 387: 616-641.

Obstfeld M. (1999). Foreign resource inflows, saving, and growth In The Economics of Saving and Growth: Theory, Evidence, and Implications for Policy, Schmidt-Hebbel K, Serven L (eds). Cambridge University Press: Cambridge, 107-146.

Pallage, S. and Robe M. A. (2001). Foreign aid and the business cycles. Review of International Economics, 9: 641-672.

Papanek, G. F. (1972). The effect of aid and other resource transfers on savings and growth in less developed countries. Economic Journal, 82: 935-950.

Pedroni, P. (1995). Panel Cointegration; Asymptotic and Finite Sample Properties of Pooled Time Series Tests, with an Application to the PPP Hypothesis. Indiana University Working Papers in Economics, 95-013.

Pedroni, P. (1996a). Fully Modi/Eed OLS for Heterogeneous Cointegrated Panels and the Case of Purchasing Power Parity. Indiana University Working Papers in Economics, 96-020.

Pedroni, P. (1996b). Endogenous Growth, Human Capital, and Cointegration for Multi-Country Panels. Working Paper, Indiana University.

Pedroni, P. (1997a). Panel Cointegration; Asymptotic and Finite Sample Properties of Pooled Time Series Tests, with an Application to the PPP Hypothesis: New Results. Working Paper, Indiana University, April.

Pedroni, P. (1997b). On the Role of Cross Sectional Dependency in Dynamic Panel Unit Root and Panel Cointegration Exchange Rate Studies.Working Paper, Indiana University.

Pedroni, P. (1998). Testing for Convergence to Common Steady States in Nonsta- tionary Heterogeneous Panels, Working Paper, Indiana University.

Singh, R.D. (1985). State intervention, foreign economic aid, savings and growth in LDCs: some recent evidence. Kyklos, 38: 216-232.

Tavares J. (2003). Does foreign aid corrupt? Economics Letters, 79: 99-106.

Temitope, L. (2013). Foreign aid and economic growth in South Africa: an empirical analysis using bounds tests. Journal of Economics and Financial Sciences, 6(1):55-66.

Van der Leeuw (1997). Oil in Azerbaijan-Black Gold and Vile Poison, Caucasus and Unholy Alliance (Edited by Antero Leitzinger), 307-314

Web link:

http://www.tika.gov.tr/en/publications/6 